\title{
Relation between some haematological abnormalities, degree of immunosuppression and viral load in treatment-naïve HIV-infected patients
}

B.A. Denue, ${ }^{7}$ W. Gashau, ${ }^{7}$ H.S. Bello, ${ }^{2}$ I.M. Kida, ${ }^{7}$ B. Bakki ${ }^{1}$ and B. Ajayi ${ }^{3}$

$$
\begin{aligned}
& \text { العلاقة بين بعض الشذوذات الهيماتولوجية، ودرجة الكبت المناعي والحمولة الفيروسية في معالجة المرضى المصابين بعدوى الإيدز }
\end{aligned}
$$

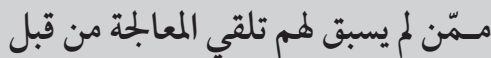

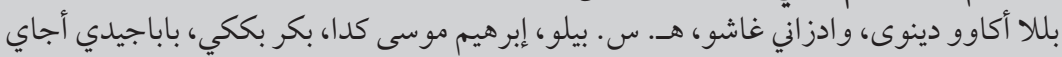

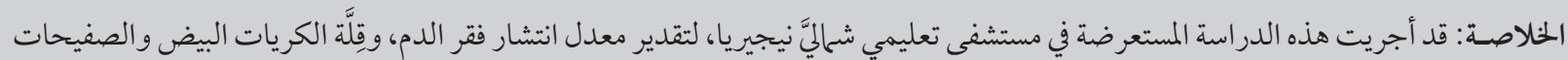

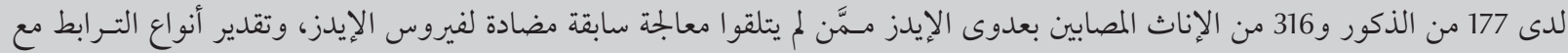

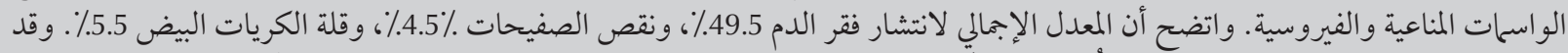

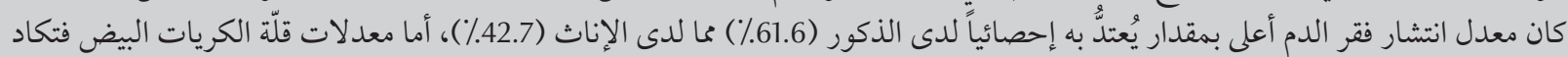

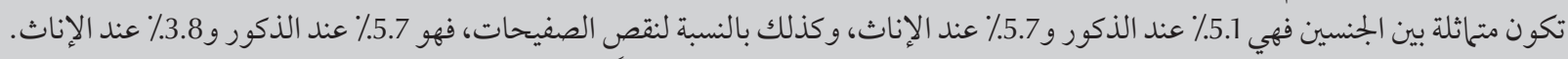

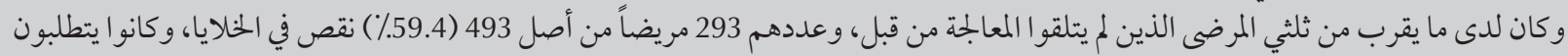

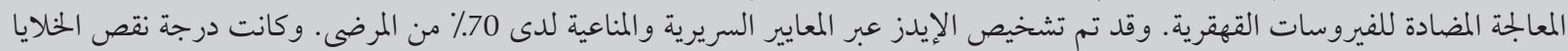

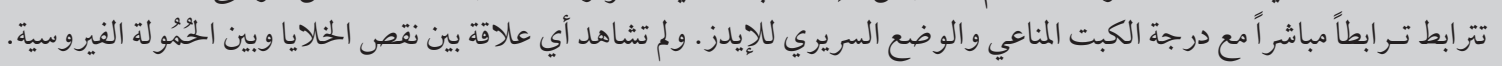

ABSTRACT This cross-sectional study at a teaching hospital in north-eastern Nigeria estimated the prevalence of anaemia, leukopenia and thrombocytopenia in treatment-naïve HIV-infected patients (177 males and 316 females), and the associations with virological and immunological markers. The overall prevalences of anaemia, leukopenia and thrombocytopenia were $49.5 \%, 5.5 \%$ and $4.5 \%$ respectively. The prevalence of anaemia was significantly higher in males than females (61.6\% versus $42.7 \%)$, while the rates of leukopenia $(5.1 \%$ versus $5.7 \%)$ and thrombocytopenia (5.7\% versus 3.8\%) were similar. Almost two-thirds of the HIV treatment-naïve studied patients, 293/493 (59.4\%), had cytopenia and would require antiretroviral drugs. AIDS was diagnosed by clinical or immunological criteria in $70 \%$ of patients. The degree of cytopenia was directly related to the degree of immunosuppression and clinical AIDS status. No relationship was observed between cytopenia and viral load.

Relation entre des anomalies hématologiques, le degré d'immunosuppression et la charge virale chez des patients infectés par le VIH et n'ayant jamais reçu de traitement

RÉSUMÉ La présente étude transversale menée dans un hôpital universitaire au nord-est du Nigeria a estimé la prévalence de l'anémie, de la leucopénie et de la thrombocytopénie chez des patients infectés par le VIH et n'ayant jamais été traités (177 hommes et 316 femmes), et les associations aux marqueurs virologiques et immunologiques. Les prévalences globales pour l'anémie, la leucopénie et la thrombocytopénie étaient de 49,5\%, 5,5\% et 4,5\%, respectivement. La prévalence de l'anémie était significativement plus élevée chez les hommes que chez les femmes (61,6 \% par rapport à 42,7\%), tandis que les taux de leucopénie (5,1 \% par rapport $5,7 \%)$ et de thrombocytopénie (5,7\% par rapport à 3,8 \%) étaient similaires. Près des deux-tiers des patients de l'étude infectés par le VIH et n'ayant jamais été traités 293/493 (59,4 \%) avaient une cytopénie et auraient besoin de médicaments antirétroviraux. Le diagnostic du sida a été posé à partir de critères cliniques ou immunologiques chez $70 \%$ des patients. Le degré de cytopénie était directement lié au degré d'immunosuppression et au stade clinique du sida. Aucun lien n'a été observé entre la cytopénie et la charge virale. 


\section{Introduction}

Haematological abnormalities (anaemia, leukopenia and thrombocytopenia) are common manifestations of advanced HIV-1 infection that could potentially limit the use of some components of antiretroviral therapy (ART) regimens $[1,2]$. The prevalence of anaemia in patients with HIV infection varies widely by sex and race/ethnicity, with rates ranging from $30 \%$ in asymptomatic HIV to as high as $63 \%-95 \%$ in persons with AIDS, depending on the study setting [3-7]. Anaemia is more common than leukopenia and thrombocytopenia in patients with AIDS [5-8]. The prevalence of leukopenia also varies widely in patients with HIV; reported prevalence ranges from $10 \%-50 \%$ $[7,8]$. Various studies have suggested that the progression of HIV, as measured by deceasing CD4+ cell counts and increasing HIV-RNA levels, is significantly associated with developing neutropenia $[6,8,9]$.

Thrombocytopenia is a possible complication of HIV infection. Its pathogenesis has not yet been established. Possible mechanisms that have been reported are an increased platelet destruction, either caused by the non-specific deposition of circulating immune complexes on platelets or by the presence of specific antiplatelet antibodies, as well as direct infection of megakaryocytes by HIV with a resulting decrease in platelet production [10].

In all cases, a specific diagnosis of the cause, severity and mechanism of cytopenia should be sought, because a specific intervention other than the use of antiretroviral drugs may be indicated for its correction. The use of antiretroviral drugs could positively or negatively affect these parameters, depending on the choice of combination used. Although many drugs used for the treatment of HIV-related disorders are myelosuppressive, severe cytopenia is most often related to the use of zidovudine [11]. Hence the need to review these parameters in a group of treatment-naïv HIV infected patients at our centre. The present study estimated the prevalence of anaemia, leukopenia and thrombocytopenia at the initiation of ART, and investigated associations between each of pretreatment anaemia, leukopenia and thrombocytopenia and baseline covariates of sex, CD4 counts and HIV-RNA viral load and clinical AIDS status at a teaching hospital in north-eastern Nigeria. The findings could inform policy and practice regarding safe provision of ART to patients who are found to have cytopenia or immunosuppression during recruitment.

\section{Methods}

\section{Study area and design}

This prospective, observational cohort study was carried out in the department of medicine at University of Maiduguri teaching hospital, Borno State from March 2008 to April 2009. This is a 500-bed hospital designated as a centre of excellence for infectious diseases and provides primary, secondary and tertiary services for the north-eastern part of Nigeria. It also caters for neighbouring countries such as Cameroon, the Niger and Chad.

Permission for the study was obtained from the University of Maiduguri teaching hospital ethics committee. Written informed consent (signed or thumbprint) was obtained from patients.

\section{Sample}

The inclusion criteria for patients were: HIV seropositive status confirmed by Western blot test; and provision of informed (written) consent. The exclusion criteria were: age < 18 years; severe renal or hepatic failure; prior history of highly active antiretroviral therapy
(HAART) usage; bleeding disorder; or inability to give consent or non-consent. All consenting participants were recruited consecutively into the study.

A total of 493 patients with HIV serological reactivity determined by enzyme immunoassay and confirmed by Western blot analysis were recruited into the study. They included patients with AIDS, diagnosed by immunological or clinical criteria based on the Centers for Disease Control 1993 revised classification for HIV infection [12]. Using a structured, preevaluated questionnaire, information was obtained on patients' demographic characteristics, clinical manifestations, medication used, blood transfusion history and sexual and drug use behaviour. Haematological parameters and viral load are free-of-charge, routine prerequisite and pretreatment evaluations done, among other ancillary investigations, for all registered HIV patients at our centre.

Haemoglobin $(\mathrm{Hb})$ and platelets count were analysed using a haematology analyser (Sysmex Corporation). Samples for total lymphocytes count and CD4+ T-cell count was collected between 09.00-10.00 hours and assayed within 6 hours of collection of whole blood using a standardized flow cytometric machine (Cyflow', Cytec). Plasma HIV-RNA levels was measured using freshly frozen specimen separated within 6 hours of phlebotomy utilizing the Amplicor HIV-1 monitor test, version 1.5 (Roche $^{\circ}$ ), with a minimum cut-off value of 200 copies $/ \mathrm{mL}$.

\section{Statistical analysis}

SPSS, version 15 statistical software was used for analysis. The results are presented as mean and standard deviation (SD). Unpaired t-test was used to compare the means of all continuous variables. Categorical data were analysed using Fisher exact test. A $P$-value of $<0.05$ was considered to be statistically significant. 


\section{Results}

\section{Background characteristics}

A total of 493 patients were consecutively recruited, consisting of 316 (64.1\%) females and 177 (35.9\%) males. The overall mean age of the patients was 34.8 (SD 8.6) years, range 15-67 years. Male patients were significantly older than their female counterparts: mean age 36.6 (SD 5.2) years (range 18-67 years) versus 32.7 (SD 8.3) years (range 15-60) years respectively $(P<0.001)$. Around $40 \%$ of the study population had no formal education. The sociodemographic and clinical characteristics of males and females are shown in Table 1.

A total of 345 patients (70.0\%) were diagnosed with AIDS by either clinical or immunological criteria. The majority were married; heterosexual transmission was the presumed risk factor in majority of our study cohort as participants denied other risky sexual behaviour that could put them at risk of contracting HIV infection.

The overall prevalence of anaemia, leukopenia and thrombocytopenia among the studied subjects, defined as $\mathrm{Hb}<10 \mathrm{~g} / \mathrm{dL}, \mathrm{WBC}<4 \times 10^{3} / \mathrm{L}$ and platelets $<100 \times 10^{3} / \mathrm{L}$, was $49.5 \%$, $5.5 \%$ and $4.5 \%$ respectively (Table 2). Anaemia was present in $109 / 177$ males $(61.6 \%)$ and $135 / 316$ females $(42.7 \%)(P=0.001)$. Nine males (5.1\%) and 18 females $(5.7 \%)(P=$ $0.78)$ had leukopenia, while 10 males (5.7\%) and 12 females (3.8\%) $(P=$ $0.33)$ were thrombocytopenic. Seven (1.4\%) patients had both anaemia and leukopenia, 4 (0.8\%) had anaemia and thrombocytopenia and none of the participants hadleukopenia and thrombocytopenia or pancytopenia.

\section{Association of AIDS status with haematological parameters}

Patients' AIDS status was associated with presence of anaemia $(P<$ $0.001)$ but not with leukopenia and thrombocytopenia (Table 2). The prevalences of anaemia, leukopenia and thrombocytopenia were $54.8 \%$, $6.1 \%$ and $5.2 \%$ in AIDS patients versus $37.2 \%, 4.1 \%$ and $2.7 \%$ respectively in patients without the features of AIDS at evaluation.

The mean $\mathrm{Hb}$ level of all patients was $10.0(\mathrm{SD} 2.5) \mathrm{g} / \mathrm{dL}$, mean WBC was $5.9(\mathrm{SD} 3.0) \times 10^{3} / \mathrm{L}$ and platelet count was 291 (SD 133) $\times 10^{3} / \mathrm{L}(\mathrm{Ta}-$ ble 3).

The mean CD4 count of the studied sample was 232 (SD 205) cells/ $\mu \mathrm{L}$, ranging from 5 to 1840 cells $/ \mu \mathrm{L}$. The mean CD4 counts for females were significantly higher than for males: 254

\begin{tabular}{|c|c|c|c|c|c|c|c|}
\hline \multirow[t]{2}{*}{ Variable } & \multicolumn{2}{|c|}{$\begin{array}{c}\text { Total } \\
(n=493)\end{array}$} & \multicolumn{2}{|c|}{$\begin{array}{c}\text { Males } \\
(n=177)\end{array}$} & \multicolumn{2}{|c|}{$\begin{array}{l}\text { Females } \\
(n=316)\end{array}$} & \multirow[t]{2}{*}{$P$-value } \\
\hline & No. & $\%$ & No. & $\%$ & No. & $\%$ & \\
\hline \multicolumn{8}{|l|}{ Marital status } \\
\hline Married & 289 & 58.6 & 109 & 61.6 & 180 & 57.0 & 0.368 \\
\hline Single & 164 & 33.3 & 51 & 28.8 & 113 & 35.8 & 0.138 \\
\hline Divorced & 27 & 5.5 & 8 & 4.5 & 19 & 6.0 & 0.620 \\
\hline Separated & 13 & 2.6 & 9 & 5.1 & 4 & 1.2 & 0.021 \\
\hline \multicolumn{8}{|l|}{ Literacy level } \\
\hline No formal education & 198 & 40.2 & 32 & 18.1 & 166 & 52.5 & $<0.001$ \\
\hline Quranic education & 35 & 7.1 & 26 & 14.7 & 9 & 2.9 & $<0.001$ \\
\hline Primary education & 116 & 23.5 & 47 & 26.6 & 69 & 21.8 & 0.274 \\
\hline Secondary education & 78 & 15.8 & 48 & 27.0 & 30 & 9.5 & $<0.001$ \\
\hline Tertiary education & 66 & 13.4 & 24 & 13.6 & 42 & 13.3 & 1.000 \\
\hline \multicolumn{8}{|l|}{ AIDS status } \\
\hline Yes & 345 & 70.0 & 116 & 65.5 & 229 & 72.5 & 0.127 \\
\hline No & 148 & 30.0 & 61 & 34.5 & 87 & 27.5 & 0.127 \\
\hline \multicolumn{8}{|l|}{$\begin{array}{l}\text { Probable route of AIDS } \\
\text { transmission }\end{array}$} \\
\hline Heterosexual & 461 & 93.5 & 157 & 88.7 & 304 & 96.2 & 0.002 \\
\hline Blood transfusion & 0 & 0.0 & 0 & 0.0 & 0 & 0.0 & - \\
\hline MSM & 0 & 0.0 & 0 & 0.0 & 0 & 0.0 & - \\
\hline IV drug use & 0 & 0.0 & 0 & 0.0 & 0 & 0.0 & - \\
\hline Unknown & 32 & 6.5 & 20 & 11.3 & 12 & 3.8 & 0.002 \\
\hline
\end{tabular}

MSM = men who have sex with men; $I V=$ intravenous. 


\begin{tabular}{|c|c|c|c|c|c|c|c|}
\hline \multirow[t]{2}{*}{ Variable } & \multicolumn{2}{|c|}{$\begin{array}{c}\text { Total } \\
(n=493)\end{array}$} & \multicolumn{2}{|c|}{$\begin{array}{c}\text { AIDS } \\
(n=313)\end{array}$} & \multicolumn{2}{|c|}{$\begin{array}{l}\text { No AIDS } \\
(n=180)\end{array}$} & \multirow[t]{2}{*}{$P$-value } \\
\hline & No. & $\%$ & No. & $\%$ & No. & $\%$ & \\
\hline \multicolumn{8}{|c|}{ Whole sample } \\
\hline Males & 177 & 35.9 & 116 & 33.6 & 61 & 41.2 & 0.131 \\
\hline Females & 316 & 64.1 & 229 & 66.4 & 87 & 58.8 & 0.131 \\
\hline \multicolumn{8}{|l|}{ Anaemia } \\
\hline Males & 109 & 61.6 & 74 & 63.8 & 35 & 57.4 & 0.503 \\
\hline Females & 135 & 42.7 & 115 & 50.2 & 20 & 23.0 & 0.000 \\
\hline Total & 244 & 49.5 & 189 & 54.8 & 55 & 37.2 & 0.000 \\
\hline \multicolumn{8}{|l|}{ Leukopenia } \\
\hline Males & 9 & 5.1 & 7 & 6.0 & 2 & 3.3 & 0.676 \\
\hline Females & 18 & 5.7 & 14 & 6.1 & 4 & 4.6 & 0.808 \\
\hline Total & 27 & 5.5 & 21 & 6.1 & 6 & 4.1 & 0.498 \\
\hline \multicolumn{8}{|c|}{ Thrombocytopenia } \\
\hline Males & 10 & 5.7 & 7 & 6.0 & 3 & 4.9 & 1.000 \\
\hline Females & 12 & 3.8 & 11 & 4.8 & 1 & 1.2 & 0.244 \\
\hline Total & 22 & 4.5 & 18 & 5.2 & 4 & 2.7 & 0.319 \\
\hline \multicolumn{8}{|c|}{ Anaemia + leukopenia } \\
\hline Males & 3 & 1.7 & 3 & 2.6 & 0 & 0.0 & 0.510 \\
\hline Females & 4 & 1.3 & 2 & 0.9 & 2 & 2.3 & 0.699 \\
\hline Total & 7 & 1.4 & 5 & 1.5 & 2 & 1.4 & 1.000 \\
\hline \multicolumn{8}{|c|}{ Anaemia + thrombocytopenia } \\
\hline Males & 1 & 0.6 & 1 & 0.9 & 0 & 0.0 & 1.000 \\
\hline Females & 3 & 1.0 & 2 & 0.9 & 1 & 1.2 & 0.969 \\
\hline Total & 4 & 0.8 & 3 & 0.9 & 1 & 0.7 & 1.000 \\
\hline \multicolumn{8}{|c|}{ Leukopenia + thrombocytopenia } \\
\hline Total & 0 & 0.0 & 0 & 0.0 & 0 & 0.0 & - \\
\hline \multicolumn{8}{|c|}{ Pancytopenia } \\
\hline Total & 0 & 0.0 & 0 & 0.0 & 0 & 0.0 & - \\
\hline
\end{tabular}

(SD 223) cells $/ \mu \mathrm{L}$ versus 194 (SD 162) cells/ $\mu \mathrm{L}(P=0.002)$. Only 42 (8.5\%) of the participants had a CD4 count of $\geq 500$ cells $/ \mu \mathrm{L}$; the majority (55.4\%) had a CD4 count $<200$ cells/ $\mu \mathrm{L}$ (Figure 1). No sex difference was observed with regard to presence of immunological AIDS status ( $<200$ cells) $\mu \mathrm{L})(P=0.512)$.

\begin{tabular}{|c|c|c|c|c|c|c|}
\hline \multirow[t]{2}{*}{ Variable } & \multicolumn{2}{|c|}{$\begin{array}{c}\text { Total } \\
(n=493)\end{array}$} & \multicolumn{2}{|c|}{$\begin{array}{c}\text { Males } \\
(n=177)\end{array}$} & \multicolumn{2}{|c|}{$\begin{array}{l}\text { Females } \\
(n=316)\end{array}$} \\
\hline & Mean (SD) & Min.-Max. & Mean (SD) & Min.-Max. & Mean (SD) & Min.-Max. \\
\hline Age (years) & $34.8(8.6)$ & $15-67$ & $36.6(5.2)$ & $23-67$ & $32.7(8.3)$ & $15-59$ \\
\hline $\mathrm{Hb}(\mathrm{g} / \mathrm{dL})$ & $10.0(2.5)$ & $3.9-35.3$ & $10.3(2.6)$ & $3.9-16.1$ & $9.9(2.5)$ & $4.5-35.3$ \\
\hline WBC $\left(\times 10^{3} / \mathrm{L}\right)$ & $5.9(3.0)$ & $1-27$ & $6.0(3.2)$ & $2-21$ & $5.8(2.8)$ & $1-27$ \\
\hline Platelets $\left(\times 10^{3} / \mathrm{L}\right)$ & 291 (133) & 10-1008 & 264 (128) & 10-837 & 306 (134) & 47-1 008 \\
\hline CD4 (cells/ $\mu \mathrm{L}$ ) & $232(205)$ & 5-1840 & $194(162)$ & 5-909 & $254(223)$ & $13-1840$ \\
\hline Viral load (copies/mL) & $\begin{array}{c}324873 \\
(879555)\end{array}$ & 200-8 480982 & $\begin{array}{c}441222 \\
(1086013)\end{array}$ & 200-7 601010 & $\begin{array}{c}259657 \\
(1086013)\end{array}$ & 200-8 480982 \\
\hline
\end{tabular}

$H b=$ haemoglobin $; W B C=$ white blood cell count $C D 4=$ cluster of differentiation -4 cells; $S D=$ standard deviation; Min. = minimum; Max. $=$ maximum . 
Among participants with CD4 count $<200$ cells $/ \mu \mathrm{L}$, anaemia was observed in 63.5\%; the corresponding prevalences were $36.3 \%, 33.9 \%$ and $19.0 \%$ respectively in cohorts within the CD4 count ranges 200-349, 350-499 and $\geq 500$ cells $/ \mu \mathrm{L}(P<0.001)$. As presented in Figure 2, an inverse association was found between risk of anaemia, leukopenia and thrombocytopenia and CD4 count, as the prevalence of cytopenia declined in patients with increased CD4 count $(P<0.001)$. HIV-1 viral load, however, was not associated with the risk of cytopenia (Figure 3).

\section{Discussion}

This study showed that $49.5 \%$ of the sample population had anaemia, which is higher than the $18.9 \%$ prevalence reported in Uganda [13] but lower than $80 \%$ obtained by Erhabor et al. in Port Harcourt, Nigeria, among untreated HIV patients [14]. This study is in agreement with previous studies by Akinsegun et al. [15], Zon and Groopman [7], Spivak et al. [16] and a multicentre AIDS cohort study showing that anaemia was directly related to the degree of immunosupression [16].

A leukopenia prevalence of $5.5 \%$ was reported in this study compared with the 10\% reported by Erhabor et al. [14]. It was also confirmed in this study that a high prevalence of leukopenia was associated with profound immunodeficiency, as was reported by Zon and Groopman [7], Spivak et al. [16] and the multicentre AIDS control cohort study [17]. A thrombocytopenia prevalence of $4.5 \%$ was shown in this study, lower than 10\% reported by Erhabor et al. [14] and $16.1 \%$ by Akinsegun et al. [15]. The degree of thrombocytopenia was also directly related to the degree of immunosupression, in agreement with Jost et al. [10] and the multicentre study [17]. A decrease in serum erythropoietin levels [16], auto-antibodies to erythropoietin or marrow suppression

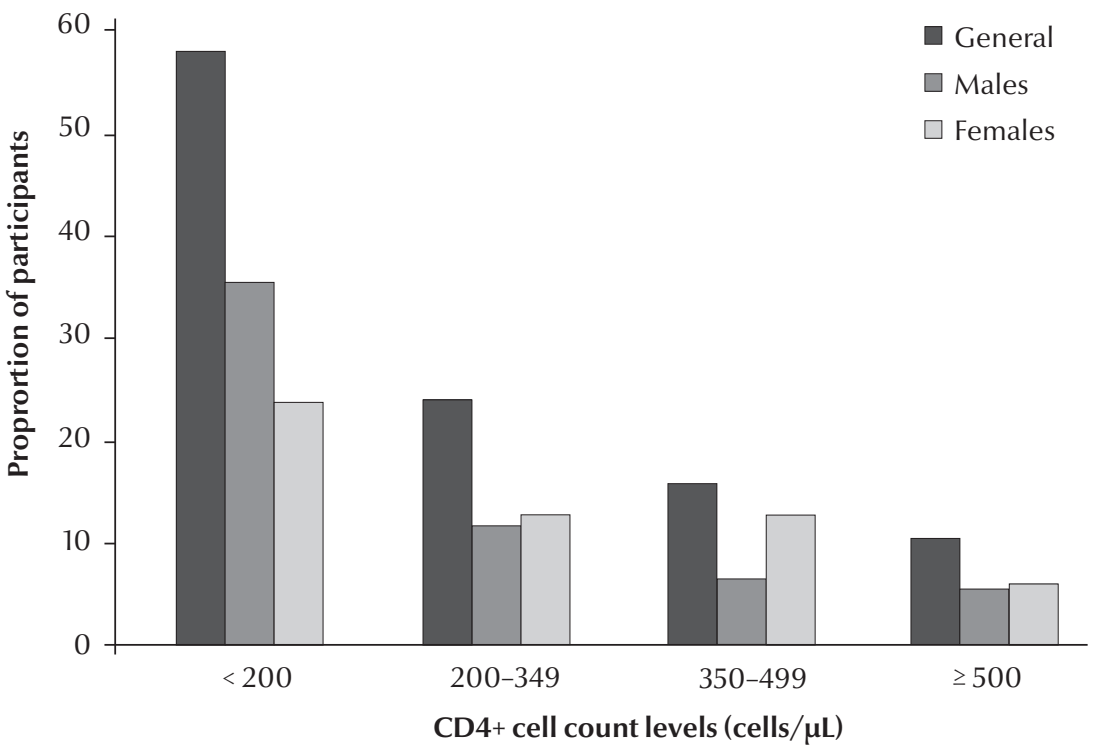

Figure 1 Distribution of CD4+ cell counts in the study group of treatment-naïve HIV-infected patients. Total $n=493$; males $n=177$; females $n=316$

by opportunistic infections, tumours or various medications $[16,18-20]$ may also contribute to the anaemia commonly observed in HIV-infected persons.

This study revealed that over half (55.4\%) of newly registered HIV patients will require antiretroviral drugs

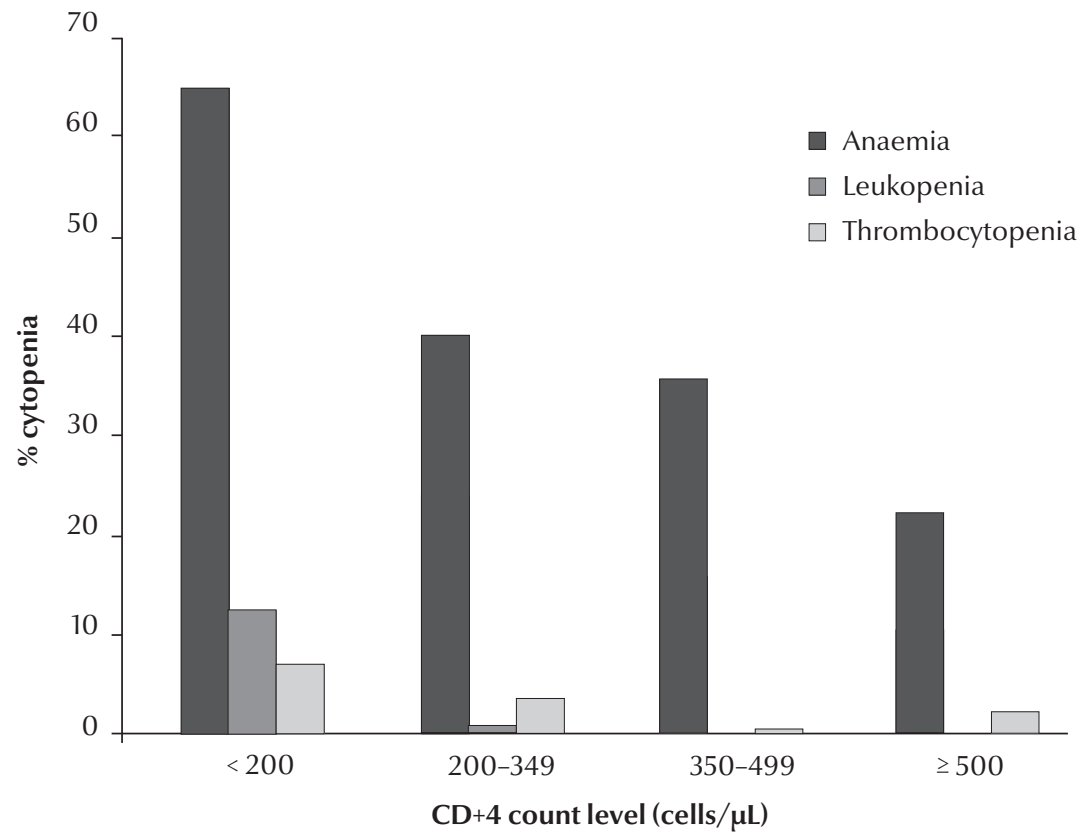

Figure 2 Relationship between CD4+ counts and cytopenia in the study group of treatment-naïve HIV-infected patients. Total $n=493$; males $n=177$; females $n=316$ 


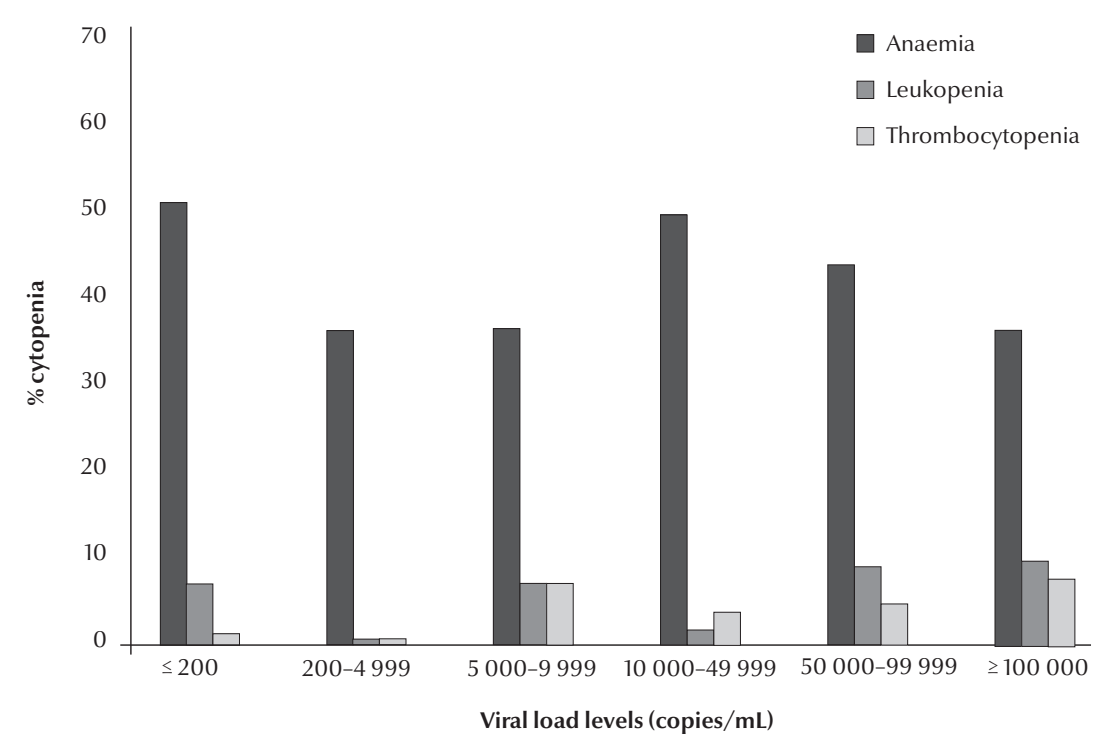

Figure 3 Relationship between viral load and cytopenia in the study group of treatment-naïve HIV-infected patients. Total $n=493$; males $n=177$; females $n=316$

this was significantly higher than the mean of 194 cells $/ \mu \mathrm{L}$ for males, similar to the study of Akinsegun et al. [15], but contrary to the study of Omoti et al. that reported a slightly higher CD4 count for males of 195 cells/ $\mu \mathrm{L}$ versus 180 cells $/ \mu \mathrm{L}$ for females [21]. Oladepo et al. established a reference value for CD4 in healthy Nigerian adults of 365-1571 cells $/ \mu \mathrm{L}$, with a mean CD4 count of 847 cells/ $\mu \mathrm{L}$ [22], and this was similar to the mean value of 828 cells $/ \mu \mathrm{L}$ reported by Aina et al. in an earlier study in Nigeria [23]. Females were found to have significantly higher absolute CD4 counts in this study. This observation of higher CD4 count in females has also been reported in several other countries among Nigerians [24], Ugandans [25] and Ethiopians [26]. A sex hormone effect is one possible explanation for the reported difference in $\mathrm{CD} 4$ counts between the sexes [26].

Patients with features of AIDS (WHO clinical stage IV) or severe immunosuppression (CD4 count < 200 cells/ $\mu \mathrm{L}$ ) had lower haemoglobin, leucocyte and platelet levels. However, unlike other reports [27-29], no relationship was observed between plasma HIV-RNA levels and cytopenia in this study. The hypothesis that HIV-1 infection of marrow stromal cells results in anaemia and other cytopenias was not supported by our study.

\section{Conclusion}

Almost two-thirds of HIV treatmentnaive patients at our centre had cytopenia and would require antiretroviral drugs, and the degree of cytopenia was directly related to the degree of immunosupression. In this study, unlike some reports, no relationship was observed between cytopenia and viral load. In view of this high prevalence of cytopenia, it is necessary to investigate its causes in these patients, and administer specific interventions.

\section{References}

1. Levine A et al. Neutropenia in human immunodeficiency virus infection: data from the Women's Interagency HIV Study. Archives of Internal Medicine, 2006, 166:405-410.

2. Berhane $\mathrm{K}$ et al. Impact of highly active antiretroviral therapy on anaemia and relationship between anemia and survival in a large cohort of HIV-infected women: Women's Interagency HIV Study. Journal of Acquired Immune Deficiency Syndromes, 2004, 37:1245-1252.

3. Doukas MA. Human immunodeficiency virus associated anaemia. Medical Clinics of North America, 1992, 76:699-709.

4. Groopman JE. Management of the hematologic complications of human immunodeficiency virus infection. Reviews of Infectious Diseases, 1990, 12:931-937.

5. Mir N et al. HIV-disease and bone marrow changes: A study of 60 cases. European Journal of Haematology, 1989, 42:339.

6. Frontiera M, Myers AM. Peripheral blood and bone marrow abnormalities in the acquired immunodeficiency syndrome. Western Journal of Medicine, 1987, 147:157.

7. Zon LI, Arkin C, Groopman JE. Haematologic manifestations of the human immune deficiency virus (HIV). British Journal of Haematology, 1987, 66:251-256.

8. Calenda V, Chermann JC. The effects of HIV on hematopoiesis. European Journal of Haematology, 1992, 48:181-186.
9. Zon LI, Groopman JE. Hematologic manifestations of the human immunodeficiency virus (HIV). Seminars in Hematology, 1988, 25:208-218.

10. Jost J et al. HIV-assoziierte Thrombozytopenie. [HIV-associated thrombocytopenia.] Schweizerische Medizinische Wochenschrift, 1988, 118:206-212.

11. RD. Keruly JC, Chaisson RE. Anemia and survival in HIV infection. Journal of Acquired Immune Deficiency Syndromes and Human Retrovirology, 1998, 19:29-33.

12. Centers for Disease Control and Prevention. 1993 revised classification system for HIV infection and expanded surveillance case definition for AIDS among adolescents and adults. Journal of the American Medical Association, 1993, 269:729-730.

13. Mugisha JO et al. Anaemia in rural Uganda HIV cohort, prevalence at enrolment, incidence, diagnosis and associated factors. Tropical Medicine and International Health, 2008, 13:788-794.

14. Erhabor $\mathrm{O}$ et al. Some haematological parameters in human immunodeficiency virus (HIV) infected Africans: the Nigerian perspective. Nigerian Journal of Medicine, 2005, 14:33-38.

15. Akinsegun A et al. Hematologic abnormalities in treatmentnaïve HIV patients. Infectious Diseases: Research and Treatment, 2010, 3:45-49. 
16. Spivak JL et al. Serum immunoreactive erythropoietin in HIVinfected patients. Journal of the American Medical Association, 1989, 261:3104-3107.

17. Kaslow RA, Phair JP, Friedman HB. Infection with the human immunodeficiency virus: Clinical manifestations and their relationship to immune deficiency. A report from the Multicenter AIDS Cohort Study. Annals of Internal Medicine, 1987, 107:474-480.

18. Frickhofen $\mathrm{N}$ et al. Persistent B19 parvovirus infection in patients infected with human immunodeficiency virus type 1: a treatable cause of anaemia in AIDS. Annals of Internal Medicine, 1990, 113:926-933.

19. Creagh-Kirk T et al. Survival experience among patients with AIDS receiving zidovudine-follow-up of patients in a compassionate plea program. Journal of the American Medical Association, 1988, 260:3009-3019.

20. Seneviratne LC et al. Clinical, immunologic, and pathologic correlates of bone marrow involvement in 291 patients with AIDS related lymphoma. Blood, 2001, 98:2358-2263.

21. Omoti CE, Udezi WA, Ediose RE. Haematological aspects of antiretroviral naïve HIV patients in a Nigerian tertiary hospital: laboratory and clinical consideration. International Journal of Biological and Chemical Sciences, 2007, 1:176-180.

22. Oladepo DK et al. Establishment of reference values of CD4 and CD8 lymphocyte subsets in healthy Nigerian adults. Clinical and Vaccine Immunology, 2009, 16:1374-1377.
23. Aina $\mathrm{O}$ et al. Reference values of CD4 T-lymphocytes in human immunodeficiency virus-negative adult Nigerians. Clinical and Diagnostic Laboratory Immunology, 2005, 12:525-530.

24. Njoku MO et al. CD4+ T-lymphocyte counts in patients with human immunodeficiency virus type 1 (HIV-1) and healthy population in Jos, Nigeria. Postgraduate Medical Journal, 2003, 10:135-139.

25. Tugume SB et al. Haematological reference ranges among healthy Ugandans. Clinical and Diagnostic Laboratory Immunology, 1995, 2:233-235.

26. Prins $\mathrm{MJ}$ et al. Do gender differences in CD4 counts matter? AIDS, 1999, 13:2361-2364.

27. Moses $A U$ et al. Human immunodeficiency virus infection of bone marrow endothelium reduces induction of stromal hematopoietic growth factors. Blood, 1996, 87:919-925.

28. Bahner I et al. Infection of human marrow stroma by HIV-1 is both required and sufficient for HIV-1 induced haematopoietic suppression in vitro: demonstration by gene modification of primary human stroma. Blood, 1997, 90:1787-1798.

29. Scadden DT et al. Human immunodeficiency virus infection of human bone marrow stromal fibroblasts. Blood, 1990, 76:317-322. 